\title{
Reflections on the Theory and Practice of Citizen Diplomacy in the Conduct of Nigeria's Foreign Policy
}

\author{
Dr. Odoh, S.I., Nwogbaga, David M.E. \\ Political Science Department Ebonyi State University Abakaliki \\ Political Science Department Ebonyi State University Abakaliki
}

\begin{abstract}
Citizen diplomacy has generated a lot of debates among intellectuals with respect to the theoretical concerns and practical implications in the conduct of foreign policy among states. The debates mainly focused on the reciprocal relationship between citizens and the state in external relations. While the citizens are expected to participate directly or indirectly, in the formulation, implementation, and evaluation of foreign policies; states are required to guarantee the welfare and security of the citizens. In essence, the theory and practice of citizen diplomacy is concerned with the participation and protection of the citizens in the foreign policy process. But debates among intellectuals so far, raised some controversial and critical issues over (a) the category of citizens to participate in the conduct of diplomacy; and (b) the category of persons to enjoy diplomatic protection. In this regard, practical instances were used to explain why the participation and protection of Nigerian citizens in the foreign policy process should not be exclusively restricted to any specific category of persons. Instead, the degree of participation and protection should vary according the conditions of the affected citizens.
\end{abstract}

\section{Introduction}

States and their citizens share bonds of inseparable relationships that cannot be ignored without consequences. This bond of relationship is expressed in the concept of citizenship which defines individuals' legitimate membership of any given state with specific rights, duties, obligations and privileges (Hoffman and Graham, 2006). Hence, the citizens constitute the primary essence and responsibility of the state. The protection of the citizens by the state is therefore a core national interest which ought not to be jeopardised but pursued at all costs in the foreign policy process. In reviewing the theory and practice of citizen diplomacy in foreign policy process, attention is focused on conceptualising "citizen" and "citizenship", exploring the origin and meaning of citizen diplomacy, identifying the dimensions of citizen diplomacy, and addressing the application of citizen diplomacy in the foreign policy process.

\section{Conceptualisation of "Citizen" and "Citizenship"}

The concepts of "citizen" and "citizenship" are originally associated with the ancient city-states of Greece where they were used to qualify individuals as members of their society based on gender, ethnic, and imperial hierarchies (Hoffman and Graham, 2006). While "citizen" is a concept used to qualify a bona fide and legitimate member of the Greek City-State, the concept of "citizenship" describes the processes and methods of becoming a citizen of a society (Marshall, 1950; Abah and Okwori, 2002; Hoffman and Graham, 2006). There are four main theoretical notions with respect to the conceptualisation of "citizen" and "citizenship": closure, communitarian, civil-republican, and liberal notions (Hoffman and Graham, 2006; Omemma, 2006).

The closure theory is associated with the aristocratic practices of the ancient Greek city-states; it restricts citizen and citizenship status to adult male members of the society who have the ability and chance to participate in government to the exclusion of the poor, slaves, foreigners, women, and children (Aristotle, 1962; Hoffman and Graham, 2006). In this context, citizens were only indigenous adult males relieved of menial tasks, national in political orientation, public in service, and have property (Marshall, 1950; Rousseau, 1968; Hoffman and Graham, 2006). The closure view point is seen to be elitist in nature as it leaves out many categories of the less privileged persons of the society as non-citizens. This attracted the criticisms of the Marxists who described the notion of citizenship as sexist and implies the rights of the egoistic man (property owner or capitalist) to exploit others (Hoffman and Graham, 2006). For the Marxists, the concept of citizenship is an anti-social instrument of exploitation and alienation in which men are separated from others and the community (Hoffman and Graham, 2006). As a result, the state believed to represent the interests of the citizens is not actually representative of the community, but acts on behalf of the property owners (Marx and Engels, 1967). This criticism may be right to the extent that citizenship status based on the binding rules and conditions of the closure adherents is only conferrable on indigenes (sons of the soil) to have access to certain exclusive privileges and life opportunities. The closure viewpoints may be associated with the acquisition of citizenship 
by birth as provided in the constitution of different countries where being an indigene is a vital determinant. In Nigeria for instance, the acquisition of citizenship by birth as provided in Chapter 3 of the 1999 Constitution requires that the person be born in or outside Nigeria before or after the date of independence, either of whose parents or any of whose grandparents belongs or belonged to a community indigenous to Nigeria or is a citizen of Nigeria (Agena, 2004). This implies that one can only claim his citizenship rights by establishing that he or she is an indigene of a community indigenous to Nigeria, else such persons shall be treated as non-citizens, foreigners, or settlers with limited access to means of livelihood (Omemma, 2006). But it should be noted that the concept of citizenship is becoming universalised beyond the closure notions to the extent that an individual resident in one country or society is recognised as a legitimate citizen of another country and be treated as such.

The communitarians on their part consider the concepts of "citizen" and "citizenship" as contractual exchanges between individuals and the community (Miller, 1995). In other words, citizenship status is a concept used to qualify the relationship established based on agreements which define the rights and obligations of the citizens with respect to the powers and duties of the state (Miller, 1995; Omemma, 2006). This implies that citizenship is a reciprocal relationship between the citizen and the state upon which the former owes some patriotic responsibilities to the later which offers public goods and protection in return. The citizen is therefore conceived here as the rational consumer of public goods provided by the state. In simpler terms, citizenship is a relational agreement between citizens (expected to carry out some obligations for the state) and the state (expected to guarantee the rights and provide needs of the citizens). In the view of the communitarians, citizens are not necessarily those people who are indigenous to a country by birth; instead, citizens are all those who have reached agreements with the state to perform functions as may be assigned to them so as to be protected and provided for, by the state. The postulations of the communitarians are in tandem with the acquisition of citizenship by registration which requires agreements and oath-taking between the applicant and the state as provided in section 34 of Nigeria's 1999 constitution and obtainable in other countries. Acquiring citizenship by registration leaves avenues for people who are not indigenes of any community in a country to become citizens through agreement with the state if the leadership is satisfied that the applicant (a) is a person of good character; (b) has shown a clear intention of his or her desire to be domiciled in the country; (c) has taken the oath of allegiance. In Nigeria, such a privilege may be granted to any woman who is or has been married to a citizen of Nigeria as well as every person of full age and capacity any of whose grandparents is a citizen of Nigeria (Agena, 2004). In essence, individuals are at liberty to decide and become citizens of any country of their choice thereby giving one the opportunity of enjoying dual citizenship.

The civil-republican notion perceives the rights of individuals to become citizens not as inherent but as acquired through civil practices (Agena, 2004; Omemma, 2006; Hoffman and Graham, 2006). Hence, one is not a citizen by simply belonging to a community or residing in a territory; but by having present and future capacity to influence politics (Agena, 2004). A citizen is therefore anyone that upholds obligation (e.g. payment of taxes) to the state as basis for protection and provision of public goods (Miller, 1995). In the light of the civilrepublican viewpoint, a citizen is refers to those who play active parts in shaping the future directions of the society or country through political debates and decision-making (Miller, 1995). In this regard anyone who assimilates the culture, traditions, beliefs, and sentiments of state or community as well as contributes to its development qualifies to be identified as a citizen (Miller, 1995). The assertions of the civil-republican proponents are closely associated with the acquisition of citizenship by naturalisation as contained in section 35 of Nigeria's 1999 Constitution. It provides that individuals may qualify to be granted citizens of Nigeria through the issuance of the certificate of naturalisation if (i) in the opinion of the Governor of the state he is from or proposes to be resident, is acceptable to the local community in which he is to live permanently and has been assimilated into the ways of life of Nigerians in that part of the federation; (ii) he is a person who has made or is capable of making useful contributions to the advancement, progress, and well-being of Nigeria; (iii) taken the oath of allegiance as prescribed in the seventh schedule of the constitution; (iv) he has immediately preceding the date of his application either resided in Nigeria for a continuous period of 15 years or resided in Nigeria continuously for a period of 12 months, and during the period of twenty years immediately preceding that period of twelve months has resided in Nigeria for periods amounting to an aggregate not less than 15 years. Meanwhile, individuals may not qualify to be citizens if they cannot make vital contributions towards national or community development.

The liberal notion as championed by Marshal (1950) holds that "citizen" and "citizenship" are inherent in individuals prior to community, and guaranteed with minimal obligations to the community or state (Miller, 1995). Citizenship in the liberal context emphasise the rights of individuals to be guaranteed and protected by the state. These rights include (a) basic-civil rights which entail freedom of speech, freedom to own property, freedom to worship and equality of justice to all; (b) political rights which embody franchise and rights to criticise government; (c) social rights which require that the citizens be protected against poverty, and have access to education and housing (Marshal, 1950; Hoffman and Graham, 2006; Omemma, 2006). In a sense, 
citizens must possess these three categories of rights in the state if their participation, welfare, and security are to be guaranteed in the society.

Without prejudice to the foregoing notions, "citizen" and "citizenship" refer to the "status" and "process" on which individuals rely to gain legitimate access to the provisions and protections of the state. The demand for citizenship must therefore be a demand for resources that make individuality not just a condition to be protected, but a reality to be attained (Hoffman and Graham, 2006). The attainment of this reality is anticipated on the grounds that citizenship requires the participation of the people in government, guaranteeing people's access to welfare services, and providing security not simply in the sense of protection against violence, but in the sense of having the confidence, the capacity, and the skills to be actively involved in decision-making. In this respect, the citizen is an essential actor in diplomacy and the conduct of foreign policy.

\section{Origin and Meaning of Citizen Diplomacy}

The concept of Citizen Diplomacy originated from the United States of America. It was first coined by David Hoffman in 1981 through an article on Dr. Robert W. Fuller's work (Wikipedia, 2011). Dr. Fuller was an American Physicist who travelled frequently to the Soviet Union in the 1970s and 1980s in effort to alleviate the cold war between the US-led capitalist West and the Russia-led socialist East. After the collapse of the Soviet Union, Dr. Fuller continued the tension-dissipating visits to the political hotspots around the world and developed the idea of reducing "rankism" to promote peace (Wikipedia, 2011).

In the course of developing the concept, different scholars described citizen diplomacy with various terms: Gullion (1965) earlier called it public diplomacy in 1965 at the Fletcher school of Law and Diplomacy when he explained it as involving the transnational flow of information and ideas through the interaction of private groups and interests of different countries. Montville (1987) addressed citizen diplomacy as "Track Two Diplomacy" when he distinguished it from traditional (Track One) diplomacy as unofficial informal interactions among the citizens of countries. Also, John McDonald and Louise Diamond referred to citizen diplomacy as "Multi-track Diplomacy" and suggested that there are many ways to bring people together in addition to official negotiations (Montville, 1987).

Without prejudice to the various terms used to describe "citizen diplomacy", it implies that individual citizens are not just the centre-piece of state policies, but also have the rights and even the responsibility to help realise the country's national interests through their interactions to complement official diplomatic activities. Hence, though citizen diplomacy has varied interpretations among scholars, it centrally implies the transnational flow of information and ideas through the interaction of private groups and interests of different countries which influence the formation and execution of foreign policies in the pursuit of national interests (Montville, 1987).

The varied interpretations and definitions of citizen diplomacy accentuated two critical elements: the participation of the citizens in the foreign policy processes and protection of the citizens by the state (PAC, 2005; Ojo, 2007; Eke, 2009; Eze, 2009). These two elements of participation and protection are very instrumental in the foreign policy of any country towards realising the stated national interests (Aja, 2009).

\section{Application of Citizen Diplomacy in the Foreign Policy Process}

The foreign policy of any state towards realizing its national interests involves three main processes which are formulation, implementation, and evaluation (Rourke and Boyer, 2002; Egbo, 2003; Udenta, 2005; Eke, 2009; Goldstein and Pevehouse, 2011). In each of these processes, the participation of the citizens is considered very essential because they determine to a very large extent, the interests that should be aggregated into national interests as to elicit their support (Aja, 2009). The involvement of the citizens in the formulation, implementation, and evaluation of foreign policy implies that the processes must be democratised (Eke, 2009). The democratisation of the foreign policy processes suggests an extensive involvement of institutions and citizens in the determination of foreign policy decisions such that there is popular influence and control of the actions and activities of government even against the will of the rulers (Nwabueze, 1993). In a sense, the opinions, supports, and constructive criticisms of the citizens are essential in enhancing foreign policy formulation, implementation and evaluation respectively. In line with this argument, the Nigerian government in its fundamental objectives and directive principles of state policy declared in section 14(ii) of the 1999 constitution that (a) sovereignty belongs to the people of Nigeria from whom government derive all its powers and authority; (b) the participation of the people in their government shall be ensured in accordance with the provisions of the constitution. The implications of these provisions with respect to citizen diplomacy and the pursuit of national interest in the foreign policy process include servant leadership, consideration of civil society opinions, involvement of other relevant institutions and agencies in decision making, and people-to-people interactions beyond official diplomatic relations without necessarily being prodded or funded by the government (Ogunsanwo, 2009; Eze, 2009; Eke, 2009). Ogunsanwo (2009) expressly gave credence to this perception of citizen diplomacy when he noted that all Nigerians abroad should see themselves as diplomats because the 
promotion and protection of Nigeria's national interests is not the exclusive preserve of the official diplomats whose tasks are already enormous and requires all hands on deck. Hence, a Nigerian going abroad should not take the position that there are professional diplomats in the various missions abroad who are paid to paint a good picture of the country's image (Ogunsanwo, 2009). It is important to note that the ordinary citizens are better placed to extend Nigeria's image to the nooks and crannies of their host country and thereby guarantee her good reputation. Invariably, an integrated and stronger citizenry would better project Nigeria's foreign policy initiatives globally (Eke, 2009).

On the contrary, a foray into the history of Nigeria's foreign policy does not reflect a democratised process but an exclusive preserve of the elites (Akinterinwa, 2007; Ogunsanwo, 2009). As a result, what the elites conceived as national interests was scarcely people-oriented. Between 1975 and 1999, the various bodies charged with the responsibility of reviewing Nigeria's foreign policy to extensively reflect the interests and needs of the citizens were not only elitist but also unsuccessful (Ogunsanwo, 2009). Among these bodies were the Adebayo Adedeji Foreign Policy Review (1975/1976), the National Advisory Council on Foreign Policy (1977-1979), the Kuru conference on Nigeria's foreign policy (1985-1987), the stillborn Tom Ikimi-sponsored Kuru Conference (1995), and the National Council on Foreign Policy (1999). While the Adebayo Adedeji Foreign policy Review left the legacy of establishing the Foreign Policy Academy in 1982, the National Advisory Council on foreign policy headed by Maj. Gen. Shehu Yar'Adua had no significant impact (Ogunsanwo, 2009). Although, the Kuru Conference of 1985-1987 sponsored by Bolaji Akinyemi was successful, the report was not published and no white paper was issued either, to announce government decision (Ogunsanwo, 2009). The proposed Kuru Conference under Chief Tom Ikimi as the then Minister of Foreign Affairs under late Gen. Sani Abacha regime could not hold and was never rescheduled due the plane crash that occurred on January 14, 1995 (the day the conference ought to commence) and claimed the life of Ibrahim Abacha (Son of the then Head of State). Importantly, the National Council on Foreign Policy organised in the civilian administration of Chief Olusegun Obasanjo under the leadership of Emeka Anyaoku did the following: (a) examined Nigeria's diplomatic machinery and recommended the closure of some Nigerian diplomatic missions abroad on grounds of inadequate funding; (b) considered the United Nations' Reforms and Nigeria's effort to gain the permanent seat in the security council; and (c) examined the second scramble for Africa. In view of the elitist orientation of the various foreign policy initiatives, it is notable that the efforts made so far lacked the input of the popular masses and therefore could not fall into the category of citizen diplomacy within the context of democratisation. This is not however to say that the efforts were anti-people, but that the ordinary Nigerians did not participate. A resemblance of citizen diplomacy was extended to Israel in 1984 by two prominent Nigerian traditional rulers (Oni of Ife - Oba Okunade and the Emir of Kano - Alhj. Ado Bayero) when the two countries were in serious diplomatic row (Birai, 1996; Fawole, 2003). The private visit to Israel by the two traditional rulers generated considerable diplomatic headache and incurred the wrath of the Nigerian government which promptly suspended them for six months, restricted them to their domains, and seized their international passports (Fawole, 2003). These actions sent strong signals that the Nigerian government did not condone their naive attempt to conduct diplomacy on its behalf. The argument was that in the first instance, they had no mandate to conduct diplomacy on behalf of the Nigerian government, and at least, not on such sensitive matter as the recognition of Israel (Fawole, 2003). This suggests that though the involvement of the citizens may be tolerated in the diplomatic process, sensitive issues should be avoided. Nonetheless, as agents of informal diplomacy, the citizens stand to complement the functions of the overstretched official diplomats who cannot in any way adequately advance Nigeria's foreign policy extensively to the nooks and crannies of each country especially in the face of limited funds, shortage of diplomatic personnel, severance of official diplomatic ties, and absence of diplomatic missions (Birai, 1996; PAC, 2005; Eke, 2009). Take for example, within the period of the diplomatic row (1973-1992) between Nigeria and Israel, the citizens of Israel doing business in Nigeria effectively served as diplomatic links for their government as they continued their transactions (Birai, 1996; Fawole, 2003). The Nigerian Diaspora could therefore serve as the country's ambassadors by exhibiting the most exemplary conduct, good behaviour and etiquette at all times if they are adequately mobilized and oriented.

With respect to protection, debates have been generated on the category of citizens to be protected: between the nationals of a country and the resident aliens; the legal and illegal migrants; those who engage in legitimate transactions and those that engage in illegitimate transactions (Ogunsanwo, 2009; Eze, 2009). In response to these issues, Eze (2009) contended as follow: first, that no state should be discriminatory in the protection of its nationals and aliens because any government or actor within the international community has rights to assess how its citizens in other countries are treated to determine how it will reciprocate towards the citizens of those other countries resident in their own state; second, both the legal and illegal migrants should be protected within the confines of national and international laws because the waves of globalisation has largely universalized citizenship beyond geo-legal constraints; third, even when the citizens of any country may be alleged to have committed any crime or engaged in illegitimate transactions, the general principle of 
presumption of innocence of the citizen(s) should apply until proven otherwise; and even when tried and convicted under due process, they should not be subjected to inhuman treatments; fourth, where there is conflict of nationalities arising from dual citizenship, the right of diplomatic protection resides with the country where the citizen has the most real and closest connection; fifth, in the case of conflicts in the laws of different states over the offence of an individual (e.g. prostitution by a Nigerian in Italy where it is only morally wrong, but legalised in the later respectively), it is still highly controversial over the laws that should prevail.

Meanwhile, the contents of Nigeria's foreign policy with respect to the protection of the citizens as expressed in citizen diplomacy include the desire to ensure that (a) Nigerians travelling or resident abroad are treated with respect by other nations; (b) the safety of the growing number of Nigerians in the Diaspora are guaranteed to invest their resources for the development of the Nigerian economy; (c) the images of Nigeria and Nigerians are improved abroad as to avoid mistreatments; (d) Nigerian Diaspora who seek consular assistance receive sufficient and timely diplomatic attention; (e) Nigerians as well as aliens at home fully enjoy their rights and privileges as citizens, etc (Eke, 2009). Consequently, the protection of the citizens is made one of the fundamental objectives and directive principles of state policy provided in Chapter II, paragraph 14(ii) of Nigeria's 1999 Constitution where it was declared that the security and welfare of the people shall be the primary purpose of government. This implies that the citizens constitute the centre, focus and major concern of Nigeria's foreign policy; as such, the country's entire diplomatic machinery should be directed mainly towards protecting them and their legitimate interests at home and abroad (Ogunsanwo, 2009). This largely informed the government's declaration of citizen diplomacy as a foreign policy response to guarantee the welfare and security of Nigerians in the pursuit of national interests. In this context, citizen diplomacy requires the government of Nigeria to more consciously resort to the calculi of the basic needs, human rights, security, and socio-economic welfare of the citizens in conducting bilateral and multilateral engagements with other nations (Opara, 2009; Ojo, 2007). The citizens are therefore perceived as both the end (essence) and the means (agents or instruments) of government (Eke, 2009). But Ashiru (2011) in his argument expressed some reservations with respect to the protection of the citizens abroad; first, he noted that a country like Nigeria cannot, and should not ask the host countries of Nigerian Diaspora not to apply their local laws on those who flout them because they would suffer similar penalty if they were found guilty of similar offences in Nigeria; second, Nigerians are not the only immigrants who are mistreated abroad as to attract special attention; third, the question of rendering consular services and other assistance to Nigerian Diaspora should not be extended to the illegal immigrants who give Nigeria bad name and image abroad because they are undesirable elements; fourth, Nigeria's foreign missions are not adequately funded to shoulder the cost of rendering consular assistance to the citizens when they get into trouble in their host countries. These arguments hold serious implications for Nigerians because they were advanced by (Olugbenga Ashiru) the then Minister of Foreign Affairs.

But it should be noted that other countries like Germany and France extend diplomatic protection to their citizens even when they are alleged to have committed crimes. For instance, in October, 2007, some foreign nationals including some French citizens were intercepted at the N'djamena Airport, Chad, with a human Cargo of 132 African Children meant for export into neo-slavery (Al-Bashir, 2008). Considering the gravity of the crime, the former president Nicolas Sarkozy immediately took flight to the Chadian Capital on a rescue mission; this showed that he cared more for his citizens than the African children (Al-Bashir, 2008). The Germans did exactly the same thing when three of their journalists were among the four persons arrested in Nigeria for alleged spying activities. No sooner had the information reached Germany than the German foreign minister landed in Abuja to rescue them irrespective of the alleged crime (Al-Bashir, 2008). Also, European countries vehemently defended their nationals who injected 40 Libyan children with the HIV virus (Al-Bashir, 2008). The instances drawn from Europe and America collectively imply that no state should forsake its citizens no matter the criminality of their misconducts. Hence, it is the primary responsibility of states to guarantee the welfare and security of their citizens at home and abroad. In this regard, it is the direct obligation of the Nigerian government to guarantee the welfare and security of the citizens (Anda, 2012; Concern, 2009).

\section{Conclusion}

The theory and practice of citizen diplomacy in Nigeria's foreign policy process seems to have been more of rhetoric than reality. This is because the formulation, implementation, and evaluation of the country's foreign policy rested more with the elites largely at the expense of the ordinary Nigerians. In this regard, realizing the emphasis on participation, welfare, and security of the people as the central concern of citizen diplomacy in the foreign policy process largely depends on the disposition of the Nigerian government in the reorientation and mobilisation of the general public. Hence, the actual application of citizen diplomacy in Nigeria's foreign policy requires a more inclusive participatory approach in which the opinions of the people count while deciding matters that affect them. 


\section{References}

[1]. Abah, O. and Okwori, J. (2002). Agendas in Encountering Citizens in the Nigerian Context. IDS Bulletin, 33(2).

[2]. Agena, J. E. (2004). Citizenship Education in Nigeria: A FundamentalApproach. Enugu: John Jacob's Classic Publishers Ltd.

[3]. Aja, F. (2009). National Interest, International Law, and Our Shared Destiny. Ibadan: Spectrum Books Ltd.

[4]. Akinterinwa, B. (2007). Transformation in International Affairs and Protection of Nigeria's National Interests. In B. Akinterinwa,Nigeria's National Interests in A Globalising World. Ibadan: Bolitag International Publishers.

[5]. Al-Bashir. (2008, February 14). Citizenship Without Honour. Vanguard, p.17.

[6]. Anda, T. (2012). Bakassi: Immigrants in their Ancestral Home. Online: http://www.ngrguardiannews.com/accessed:30.10.2012.

[7]. Aristotle (1962). The Politics. Harmondsworth: Penguin.

[8]. Ashiru, O. (2011). Nigeria's Foreign Policy: Gains and Losses. Retrieved $03 \quad 08, \quad 2012, \quad$ from $\quad$ The Nation $\quad$ Web $\quad$ site: http://www.thenationonlineng.net

[9]. Birai, U. (1996). Domestic Constraints on Foreign Policy: The Role ofReligion in Nigeria-Israel Relations, 1960-1996. Kaduna: SahabPress.

[10]. Concern (2009). Displacement: How Can International Community helpDisplaced People Rebuild their Lives: A Focus on the Democratic Republic of Congo. US: World Wide Incorporated.

[11]. Egbo, S. (2003). Nigeria and the Third World: A Treatise on Foreign Policy.Enugu: John Jacob's Classic Publishers Ltd.

[12]. Eke, A. O. (2009). Globalisation Challenges and Nigerian Foreign Policy. Abakaliki: WillyRose and AppleSeed Publishing Coy.

[13]. Eze, O. (2009). Citizen Diplomacy: Legal Perspective, National andInternational Dimension. In O. Eze, Citizen Diplomacy. Lagos: PrintServe Ltd.

[14]. Fawole, W. (2003). Nigeria's External Relations and Foreign Policy UnderMilitary Rule, 1966-1999. Ile-Ife: Obafemi Awolowo University Press.

[15]. Goldstein, J., and Pevehouse, J. (2011). International Relations. New York:Pearson.

[16]. Gullion (1965). Track II Diplomacy: Can Unofficial Talks Avert Disaster?Retrieved 10 17, 2012, from Carnegie Web site: http://carnegie.org/carnegie_reporte

[17]. Hoffman, J., and Graham, P. (2006). Introduction to Political Concepts.London: Longman.

[18]. Marshall, T. H. (1950). Citizenship and Social Class and Other Essays.Cambridge: Cambridge University Press.

[19]. Marx, K. and Engels, F. (1967). The Communist Manifesto.Harmondsworth: Penguin.

[20]. Miller (1995). The Crisis of Nigerian Citizenship: Issues and Problems. InS. Odoh, and J. Onuoha, Peace and Conflict Studies in Africa. Enugu: Jones Communication Publishers.

[21]. Montville, J. (1987). Track II Diplomacy: Can Unofficial Talks Avert Disaster? Retrieved October 17, 2012, from Carnegie Reporter Web site: http://carnegie.org

[22]. Nwabueze, B. (1993). Democratisation. Owerri: Spectrum Law Publishing.

[23]. Omemma, T. J. (2006). The Crisis of Nigerian Citizenship: Issues andProblems. In: Odo, S. I. and Onuoha, J. (eds). Peace and Conflict Studies in Africa. Enugu: Jones Communications Publishers.

[24]. Ogunsanwo, A. (2009). Citizen Diplomacy: Challenges for Nigeria's ForeignPolicy. In O. Eze, Citizen Diplomacy. Lagos: PrintServe Ltd.

[25]. Ojo, M. (2007). Citizen Diplomacy and the Citizen. Retrieved July 15, 2010,from This Day Web site: http://www.thisdayonline.com/news

[26]. Ojo, M. (2008, April 16). Re-shaping the Nation's Foreign Policy at 50. TheGuardian, p. 15.

[27]. Ojo, O. (1986). Nigeria and Israel. In G. O. Olusanya, and R. A. Akindele,Nigeria's External Relations: The First 25 Years. Ibadan: University Press Ltd.

[28]. Opara, J. (2009, June 24). Citizen Diplomacy-Maduekwe Rolls Out theDrum, Defends Yar'Adua. This Day .

[29]. Presidential Advisory Council (PAC) (2005), "Foreign Policy in Nigeria'sDemocratic Transition". Abuja: PrintServe Ltd.

[30]. Rourke, J. T., and Boyer, M. A. (2002). World Politics: International Politicson the World Stage. USA: McGraw-Hill Book Company.

[31]. Rousseau, J. J. (1968). The Social Contract. Harmondsworth: Penguin.

[32]. Wikipedia (2011). Citizen Diplomacy. Retrieved July 10, 2010, from Wikipedia Web site: http://en.wikipedia.org

[33]. Udenta, J. (2005). Keeping the Flags Flying: A Grammer of Foreign Policy. Enugu: New Generation Books. 